DOI 10.18551/rjoas.2019-02.11

\title{
DETERMINANTS OF FARMERS' DECISIONS IN THE TAKING OF AGRICULTURAL SECTOR CREDIT: A STUDY IN LAMAKNEN SUBDISTRICT OF BELU REGENCY, EAST NUSATENGGARA PROVINCE, INDONESIA
}

\author{
Lika Ernestina* \\ Master's Program, Faculty of Economics and Business, University of Brawijaya, Indonesia \\ Sasongko, David Kaluge \\ Faculty of Economics and Business, University of Brawijaya, Indonesia \\ *E-mail: ernestinalika@gmail.com
}

\begin{abstract}
The development of the agricultural sector has limitations in increasing production. At this time, the productivity of the agricultural sector is still low; one of them is caused by capital constraints, both internal and external. This study aims to examine the influence of land ownership area $\left(X_{1}\right)$, education $\left(X_{2}\right)$, income $\left(X_{3}\right)$, and counseling service $\left(X_{4}\right)$ to the decisionmaking of agricultural credit $(Y)$ in Lamaknen Subdistrict Belu Regency East Nusa Tenggara Province. This study uses a quantitative method with the population namely all farmers in Lamaknen Sub-district consisting of 10 village units. Furthermore, the samples studied namely all farmers in Makir Village. The sampling technique used is probability sampling. Primary data was obtained using a questionnaire and then tested with the Logistic Regression analysis method. The results of the analysis show a significance value $<\alpha(0,05)$ with the Negelkerke $R$ Square value equal to 0,617. Thus, it can be concluded that the area of land ownership $\left(X_{1}\right)$, education $\left(X_{2}\right)$, income $\left(X_{3}\right)$, and counseling service $\left(X_{4}\right)$ had a significant influence on the decision making of agricultural credit $(\mathrm{Y})$ with an influence of $61,7 \%$. The right credit decision making also contributes to an increase in agricultural production, so that needed cooperation between village government and credit institutions to provide socialization to farmers related to agricultural business credit.
\end{abstract}

\section{KEY WORDS}

Determinants, agricultural credit, farmers' decisions, public service.

Agriculture is one of the main sectors for the people of Indonesia. Physioculturists argue that the agricultural sector is the only basic productive activity in developing countries, where rural and remote communities are able to escape from difficulties and poverty (Gounder and Xing, 2012; Oduol et al., 2017). One of the regions in Indonesia that has a productive agricultural sector is East Nusa Tenggara Province, with the majority of the population being farmers $(53.32 \%)$ based on 2017 survey data. Agriculture in East Nusa Tenggara Province consists of several sub-sectors, namely food crops, plantations, livestock, fisheries, and forestry. From these sub-sectors, food crops are the most attractive sub-sector to be explored because it is the main source of life for the people of East Nusa Tenggara.

As a potential agricultural area, the development of the agricultural sector in East Nusa Tenggara is very necessary to be developed by seeking to increase the agricultural production result. According to Priyanto (2015), the productivity of the agricultural sector in East Nusa Tenggara consists of upland rice, lowland rice, corn, peanuts, green beans, cassava, and sweet potatoes. Agricultural productivity in East Nusa Tenggara in 2013 was still far from the national average agricultural productivity $(55,90 \%)$, which only reached $26,40 \%$. Subsequently, in 2014 increased to $40,60 \%$, while in 2015 it declined slightly to $40,10 \%$. This shows that agricultural productivity in East Nusa Tenggara Province is still volatile and requires attention to be able to increase agricultural productivity. The low development of productivity in the agricultural sector is caused by various obstacles, such as natural conditions, markets and institutions, government policies, and so forth. 
One of the factors that can affect the productivity of the agricultural sector is capital. Capital is the main and most important asset in developing a farmer's business (Soekartawi, 2002). Mubyarto, 1977(in Mulyaqin, 2016), explained that capital is an important production factor after land in agricultural production in a broad sense and greatly affected the value of production. In this case, there are often found farmers who have limited capital in running their agricultural businesses so that farming activities are limited to existing financial capabilities. This capital problem can be solved by applying for agricultural credit, but on the other hand, not all farmers are aware and want to apply for credit for agricultural activities. Based on the Regional Financial Economics Study / Kajian Ekonomi Keuangan Regional (KEKR) of Indonesian Bank from East Nusa Tenggara Branch, Credit growth in the East Nusa Tenggara Province sectorally in 2016-2018 are as follows:

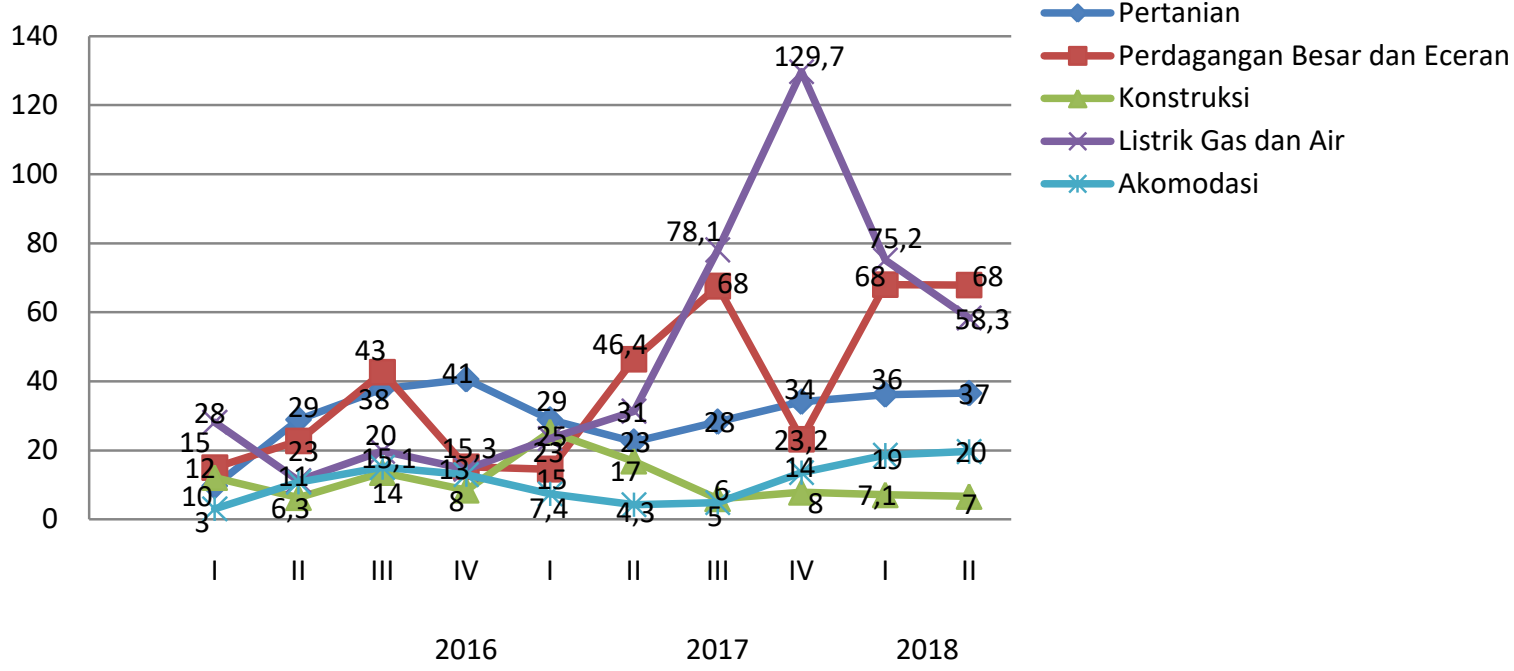

Figure 1 - Development of Sectoral Loan/Credit Distribution in NTT Province (KEKR NTT, 2018)

Based on these data, it can be seen that the average development of sectoral credit distribution from the first quarter of 2016 to the second quarter of 2018 experienced an increasing trend. This was due to growth in the sector of electricity, gas and water, wholesale and retail trade. Furthermore, when viewed from the average lending/credit distribution, the agricultural sector is above the average sectoral lending/credit distribution. Nevertheless, the increase in the distribution of the agricultural sector was driven by other subsectors, namely livestock. So it can be stated that the development of the credit distribution in the agricultural sector is still below the average sectoral credit development. Along with the slow growth of credit in the agricultural sector, the government through banks has allocated credit in various regencies or regions in East Nusa Tenggara Province. Data shows that lending/credit distribution is still concentrated on the island of Timor with a rate of $18 \%$. However, developments on other islands are still relatively good compared to Timor Island. The same thing happened to Third Party Funds (TPF)/Dana Pihak Ketiga (DPK) where the highest growth was found on Flores Island with a nominal of TPF/DPK 5,45\%, meanwhile credit growth is greater on Timor Island because economic growth is concentrated on Timor Island.

Belu Regency is one of the areas on the island of Timor, where the majority of the population is farming. Belu Regency is considered potential because it has a strategic location, which is bordered with Timor Leste. The need for economic development in the agricultural sector is very needed to create market competition. On the other hand, in increasing agricultural yields, the capital needed is more, depending on the area of land managed by farmers. Mulyaqin (2016) explained that the more land managed by farmers, the greater the effort to utilize available capital resources. Credit is one of the sources of capital that can drive an increase in agricultural products. Hernanto (1992) added that capital factors play an important role and must be considered by farmers before conducting farming. Capital 
is needed to procure production facilities, such as seeds, fertilizers and pesticides, but the price of these facilities is increasingly expensive.

Previous research conducted by Ciaian (2012) shows that developing the agricultural sector requires an increase in farmer inputs, one of which is capital. The existence of credit and input subsidies for farmers in the agricultural sector will be followed by an increase in productivity if improvement efforts are targeted at each farmer. Furthermore, Fahad's research (2018) found that in Pakistan there was crop insurance for farmers, but in making decisions to use insurance, many obstacles related to climate risk or natural factors. In addition, the role of agricultural counselor to assist farmers is also not optimal. This finding explains that counseling services, age, income, land area affected the farmers' decisions in using crop insurance. Based on agricultural credit distribution which tends to decrease and the existence of gaps in the empirical results, then this study aims to examine the determinants of farmers' decisions in taking the credit in Lamaknen Subdistrict. The determinant factors in this study include the extent/area of land ownership, education, income, and counseling services.

\section{METHOD OF RESEARCH}

The type of data used in this study is primary data taken using a questionnaire. Primary data consists of respondents' answers on a Likert scale that represent research variables. The respondents studied namely all farmers in Makir Village, Lamaknen Subdistrict Belu Regency East Nusa Tenggara Province. The sampling technique used is probability sampling. The secondary data consists of data from the department or relevant agencies as well as various literature that supports the study of research material. Data retrieval conducted in October - November 2018. Analysis of research data was carried out using the Logistic Regression analysis method with the assist of the SPSS 21 program. The variables analyzed among others the extent/area of land ownership $\left(X_{1}\right)$, education $\left(X_{2}\right)$, income $\left(X_{3}\right)$, and counseling service $\left(X_{4}\right)$ as an independent variable, as well as the decision-making of agricultural credit $(Y)$ as the dependent variable). In the decision making of the analysis results, this study uses a real level value / nilai taraf nyata $(\alpha)$ of 0,05 or $5 \%$.

\section{RESULTS AND DISCUSSION}

Results of Logistic Regression Analysis. In this study, to explain the presence or absence of the influence of the independent variable on the dependent variable is conducted by comparing the Wald statistical value with the Chi-square comparison value at the degree of freedom / derajat kebebasan $(\mathrm{db})=1$ at alpha $5 \%$, which is equal to 3,841 . If the Wald value is greater than the Chi-square value of the table or the significance value is smaller than alpha $5 \%$, then it is concluded that there is a significant influence between the independent variable and the dependent variable. A summary of the results of the Logistic Regression analysis is shown in the following table 1 :

Table 1 - Summary of Results of Logistic Regression Analysis

\begin{tabular}{|c|c|c|c|c|c|c|c|}
\hline \multicolumn{2}{|c|}{$n / n$} & $B$ & S.E. & Wald & Df & Sig. & $\operatorname{Exp}(\mathrm{B})$ \\
\hline \multirow{5}{*}{ Step $1^{a}$} & $\mathrm{X} 1$ & ,336 & ,102 & 10,790 & 1 &, 001 & 1,400 \\
\hline & $\mathrm{X} 2$ & $-2,903$ & 1,023 & 8,047 & 1 & ,005 & ,055 \\
\hline & X3 & 5,6625E-7 & $2,178 \mathrm{E}-7$ & 6,759 & 1 & ,009 & 1,000 \\
\hline & $\mathrm{X} 4$ & ,242 & ,099 & 5,897 & 1 &, 015 & 1,273 \\
\hline & Constant & $-8,195$ & 1,905 & 18,504 & 1 &, 000 &, 000 \\
\hline
\end{tabular}

Source: Research data processed (2018).

The logistic regression equation formed based on the table above is as follows:

$$
\operatorname{Ln} \frac{P}{1-P}=-8,195+0,336 \times 1-2,903 \times 2+5,6625 \mathrm{E}-7 \times 3+0,242 \times 4
$$


The Area of Land Ownership (X1). At the variable of The Area of Land Ownership (X1), obtained Wald value of $10,790(>3,841)$ with significance value $0,001(<\alpha 0,05)$. So, it can be stated that there is a significant influence between the area of land ownership (X1) on the credit decision making (Y). The regression coefficient obtained has positive sign $(+)$ indicating that the more land area that the farmer has, the higher the credit decision making.

Education (X2). At the variable of Education (X2), obtained Wald value of 8,047 (> $3,841)$ with significance value $0,005(<\alpha 0,05)$. So, it can be stated that there is a significant influence between education (X2) on the credit decision making (Y). The regression coefficient of education (X2) variable which is negative (-) indicates that the higher the farmer's education, the lower the decision to take the agricultural credit.

Income (X3). At the variable of Income (X3), obtained Wald value of 6,759 $(>3,841)$ with significance value $(<\alpha 0,05)$. Means that, there is a significant effect between the income variable $(\mathrm{X} 3)$ on the variable of credit decision-making $(\mathrm{Y})$. The regression coefficient obtained has positive sign (+),so that if farmers' income is higher, then the decision to take the agricultural credit will also be higher.

Counseling Service (X4). At the variable of Counseling Service (X6), obtained Wald value of $5,897(>3,841)$ with significance value $0,015(<\alpha 0,05)$. Means that, there is a significant effect between counseling service (X4) to the credit decision-making ( $Y$ ). The regression coefficient obtained has positive sign (+), so that it can be stated that the better the counseling service, the higher the decision to take the agricultural credit by farmers.

Furthermore, the results of the Logistic Regression analysis can also show how much influence of all the independent variables on the decision to take the agricultural credit. This assessment can be seen from the coefficient of determination.

Table 2 - Coefficient of Determination

\begin{tabular}{|c|c|c|}
\hline-2 Log likelihood & Cox \& Snell R Square & Nagelkerke R Square \\
\hline 95,542 & 0,463 & 0,617 \\
\hline
\end{tabular}

Source: Research data processed (2018).

Based on the table above, it can be seen that the value of Negelkerke $R$ Square obtained is 0,617 . So that it can be stated that the amount of the influence of the variable of the Area of Land Ownership (X1), Education (X2), Income (X3) and Counseling Service (X4) on the Credit Decision Making $(\mathrm{Y})$ is equal to $61,7 \%$.

\section{DISCUSSION OF RESULTS}

The results of the analysis show that the area of land ownership has a significant effect on credit decision making. Selain itu, the higher the area of land ownership, the higher the decision to take the agricultural credit. The results of this study are in line with the research of Murwiati (2007) where the extent/area of land ownership has a positive correlation with credit decision making. This is strengthened by Mulyaqin's research (2016) which found that the area of land ownership is one of the main factors in the utilization of the source of farming capital for farmers. In his research, it was stated that the area of land ownership also positively correlated on the credit decision making. In addition, the results of Ciaian's (2012) study also show that land area is one of the inputs for farmers, so it has a positive influence on credit decisions. Fahad's (2016) research also confirms that the wider the area of land ownership, the higher the farmer's decision to take the crop insurance. This finding is especially obtained for farmers who own land in areas with high climate risk.

In the education variable, it was found that there was a negative and significant influence between education and farmers' decisions in taking agricultural credit. The higher the education of farmers, the decision of farmers in taking the credit will tend to decrease. The results of this study contradicted with the results of the study of Ambarita (2016) which shows that education does not affect the decisions of farmers in using Credit Union (CU) as a farming finance institution. Furthermore, Mulyaqin (2016) also explained that education 
does not affect the utilization of farmers' sources of capital. In general, it can be stated that even though the farmer has a high educational background, the farmer does not necessarily decide to take agricultural credit, and vice versa. On the other hand, farmers have a tendency to take credit because of the influence of family habits, and not because of their level of education. This makes the farmer already knows and understands about credit procedures and their benefits. Bauer's research (2016) also presents results that are not in line with this study, where education has a positive correlation to the rural farmers' credit access. In his findings, it was mentioned that internal factors are more important, where low educated farmers have the potential to lose land status so the probability of credit also tends to be low.

In the income variable, the results show that income has a positive and significant influence on the decision to take agricultural credit. This finding is in line with the results of Bauer (2016) and Ambarita (2016) research, that farmers' income has a positive correlation with credit loans. It is stated that farmers with high income will tend to take credit. In this study, the average income of farmers is less than Rp.2,000,000 per month. With the main job as a farmer and low income, the farmers will find it difficult to make the credit decisions with the main consideration namely whether they can afford to pay the loan installments. Furthermore, in Mulyaqin's study (2016), it was found that income did not affect the utilization of farming capital resources because farming was not the main source of income, but rather as a side business. The results of this study also found that respondents in taking credit always consider the good and bad credit. On the other hand, farmers prefer to obtain capital from other alternatives, such as livestock products. Respondents prefer to sell livestock for farming capital rather than applying for credit to credit institutions.

In the extension/counseling service variable, the results of analysis show that there is a positive and significant influence between counseling services and farmers' decisions in taking the agricultural credit. This finding is in line with Fahad's (2018) research that counseling service has a positive correlation with farmers' decisions regarding crop insurance. Extension/counseling service is the most important factor for farmers in improving farming, either counseling service from agriculture as well as financial institutions. The higher the counseling from related institutions, the higher the probability of farmers to take credit. Furthermore, the results of the Djoumessi (2017) study also emphasize that extension/counseling service has a positive and significant influence in improving farming efficiency and is one of the socio-economic factors that need to be considered. This means that good counseling services by agricultural officers will be able to increase farming productivity. The results showed that 30 from 125 respondents had never attended counseling in a year. Interviews with the Village Head and PPL officers show that agricultural counseling is held from various institutions more than 3 times a year. This is certainly very good for increasing farmers' understanding of the importance of applying for agricultural credit. Bauer (2016) explains that farmers who receive a lot of counseling services will tend to be more motivated to take credit to improve farming.

\section{CONCLUSION AND SUGGESTIONS}

The probability of a farmer's decision to take credit is determined by the amount of the area of land ownership, education, income and counseling services. The results show that farmers who have large land, high educational background, high income, and the existence of good extension/counseling services will be more likely to take agricultural credit. The higher decision to take credit will later support an increase in farming productivity.

Based on the results of the study, the suggestions that can be given include the following:

- The need for control from the government on the price of agricultural products to maintain price stability and increase farmers' income;

- The need to increase the number of PPL in order to provide maximum extension/counseling services; 
- Village governments and credit institutions work together in an effort to increase farm productivity in climate-prone areas;

- The next researcher is advised to investigate further related to other factors that are thought to influence farmers' decisions in taking credit.

\section{REFERENCES}

1. Ambarita, D. M., \& Chalil, E. (2016). Faktor-faktor yang Mempengaruhi Keputusan Petani dalam Menggunakan Credit Union ( $\mathrm{Cu}$ ) sebagai Lembaga Pembiayaan dalam Usahatani (Studi Kasus: Cu Sondang Nauli Kabupaten Karo and Kabupaten Simalungun). Journal of Agriculture and Agribusiness Socioeconomics, 5(1).

2. Bauer, S. 2016. Does Credit Access Affect Household Income Homogeneously Across Different Groups of Credit Recipients? Evidence FromRural Vietnam. Journal of Rural Studies, 47, 186-203.

3. Ciaian, P., Fałkowski, J., \& Kancs, D. A. 2012. Access to Credit, Factor Allocation and Farm Productivity: Evidence From the CEE Transition Economies. Agricultural Finance Review, 72(1), 22-47.

4. Djoumessi, Y., Afari-Sefa, V., Kamdem, C. B., \& Bidogeza, J. C.2018. Socio-Economic and Institutional Factors Underlying Efficiency of Smallholder Vegetable Farms in Southwest Region of Cameroon. International Journal of Social Economics, 45(1), 93106.

5. Fahad, S., Wang, J., Hu, G., Wang, H., Yang, X., Shah, A. A. \& Bilal, A. 2018.Empirical Analysis of Factors Influencing Farmers Crop Insurance Decisions in Pakistan: Evidence From Khyber Pakhtunkhwa Province. Land Use Policy, 75, 459-467.

6. Hernanto, 1992.Keragaman Penyaluran Kredit pertanian.: Suatu Analisis Data Makro, Monograph Series, 3: 63-85.

7. Kajian Ekonomi and Keuangan Regional. 2016 - 2018. Kantor Perwakilan Bank Indonesia Provinsi Nusa Tenggara Timur.

8. Murwiati, Asih. 2007. Analisis Faktor-Faktor Sosial Ekonomi yang Mempengaruhi Keputusan Petani Dalam Mengambil Kredit (Studi kasus di Desa Hargotirto Kecamatan Kokap Kabupaten Kulon Progo Propvinsi Daerah Istimewa Yogyakarta). Tesis. Universitas Brawijaya. Malang. 8-11.

9. Mulyaqin, T., Astuti, Y., \& Haryani, D. 2006.Faktor Yang Mempengaruhi Petani Padi Dalam Pemanfaatan Sumber Permodalan: Studi Kasus Di Kabupaten Serang Provinsi Banten.

10. Priyanto, D., \& Diwyanto, K. 2015. Pengembangan Pertanian Wilayah Perbatasan Nusa Tenggara Timur and Republik Demokrasi Timor Leste. Pengembangan Inovasi Pertanian, 7(4), 207-220.

11. Soekartawi, 2002.Faktor-faktor Produksi. Salemba Empat, Jakarta. 